\title{
Improving the Students' Learning Concentration Through Ice Breaking
}

\author{
Ulfi Andrian Sari 1,",Nailul Fauziyah ${ }^{2}$, Ahmad Ghozi ${ }^{3}$, Ika Nur Azizah ${ }^{4}$, Ulin \\ Farischa Al-Fidyah ${ }^{5}$
}

1, 2,3,4,5 Universitas Islam Negeri Maulana Malik Ibrahim Malang, Indonesia

*Corresponding author.Email: ulfiandriansari@uin-malang.ac.id

\begin{abstract}
This study aims to increase the students' learning concentration through ice breaking. It employs classroom action research method conducted in Islamic Junior High School (MTs) Surya Buana Malang subjecting 86 students of class VIIA, VIIB, and VIIC. To measure the students' learning concentration, observation sheet is used. The research steps are (1) planning, (2) action, (3) observation, and (4) reflection. The data of the students' concentration were analyzed by using the formula of frequency distribution. The research result in cycle 1 shows that students' ability refers to the category of Less Developing $(\mathrm{LD})=17 \%$, Developing $(\mathrm{D})=33 \%$, and Developed as Expected $(\mathrm{DE})=50 \%$. In cycle 2 , ice breaking for the students' concentration manages to reach the desired targets, which are $\mathrm{LD}=10 \%, \mathrm{D}=23 \%$, and $\mathrm{DE}=67 \%$. The cycle 1 and cycle 2 results show an increase in the number of students who are in the category of DE by $17 \%$. Finally, it concludes that ice breaking can increase the students' learning concentration.
\end{abstract}

Keywords: Ice Breaking, Students' Learning Concentration, Social Science

\section{INTRODUCTION}

Social Science (IPS) education is perceived less interesting because it contains a lot of concepts and rote memorization. Students must understand the basic concepts of integrated social science. Most of the students who are less capable of understanding a concept do not like to study social science. They tend to be bored and sleepy in the classroom [1]. The preliminary observations in the class VII of MTs Surya Buana Malang reveals that the students are less interested in the learning material of social science, so they are sleepy, not listening to the teacher's explanation, and noisy. They are likely bored as they are silent, daydreaming, and careless towards the tasks given by the teachers. The continuous boredom may lead to the decline of the concentration level of students. Boredom must have ever been experienced by all students. It is a state in which the mind wants a new change and expect to stop the monotonous learning process. According to Winkel, less comfort in following the lesson will hinder the students' understanding and level of concentration [2].

Students' boredom in the classroom can be overcome by creating a fun learning. There are several ways that can be used to increase the concentration of students with by restoring the meaningful, joyful, fun, and creative atmosphere, i.e., by using the method of learning while playing. The application of this method can lead to the fun way of learning, so the students can acquire the knowledge and experience of the learning process easily [3]. Ice breaking in the class can be used to dilute the atmosphere, to control the learning concentration, and to remember the learning materials [4]. Ice breaking is a transition from being sleepy, boring, and tedious. The anxiety becomes relaxed, excited, and there's attention and a sense of fun to listen or see the one talking in the front. Ice breaking can create a pleasant, serious, but relaxed learning atmosphere.

In general, teachers uses most of his time for delivering the material in the classroom, neglecting the 
students' absorption capacity [5]. They usually do not pay attention to the weekly conditions of the students. They pay more attention to the achievement of the learning objectives rather than the mental condition of the students, so students can easily experience fatigue, boredom, anxiety, and fear at learning. They rarely concern on the influence of the subject change during the learning, whether they are tired, bored, or less interested in them.

Rarely, do the teachers provide ice breaking during the learning process. Because, they are still confused to find the material for ice breaking. Whereas, it is very important in either the beginning or in the middle of learning. Ice breaking in the opening aims to attract the students' attention by providing the learning stimulus related to the learning material. Ice breaking during the learning process functions to fill in a fun activity. The ice breakings that can be integrated into the learning process are applauses, yells, singing, playing games, and so on. A learning process interspersed with ice breaking is expected to break the rigid and tense atmosphere, so the student's brain is fresh again. The students who learn happily will experience a concentration improvement. Ice breaking can foster a spirit, create a fan atmosphere, and make learning more interesting.

The benefits of doing the activity of ice breaking are breaking the boredom, anxiety, and fatigue while the activity is motion-free and cheerful. Ice breaking can also train the students to think creatively and broadly, develop and optimize the students' brain and creativity, to think systematically and creatively, to solve problems, and to set a well-prepared strategy. Therefore, it can be used as an alternative solution for the teachers to solve non-academic-related problems and to improve the learning objective achievement. A fun and interesting learning will increase understanding, enhance a memory, and provide opportunities to the learners for the proper functioning of brain memory, so it can think optimally [6]. The optimization of the students' concentration in the learning process should also be taken into consideration by educators. This concentration triggers the absorption during the learning and teaching process in the classroom. Every student basically has the ability to concentrate or focus on one thing, such as a certain lesson, but they have different level respectively. The ability to focus (concentrate) for certain period of time is not naturally given, but it is rather the results of the daily experience.

Students can only be concentrated for a few minutes. Students' concentration only last approximately 20 minutes. While learning IPS usually takes at least 45 minutes, so their focus will obviously be reduced. They are usually sleepy, bored, noisy, indifferent in receiving the material [7]. Their learning concentration is influenced by their respective brain to focus on what is being studied. The concentration focus aims to increase the possibility of the students to absorb and understand the information delivered [8]. Concentration is one factor that can lead the students to achieve the success on the learning objectives. Those who concentrate will record better in memory. The material is easily learned, and it can be easily delivered when needed [9]. Effective concentration is the maximum focus of someone's attention at an object of activity done, and it happens automatically and easily because the person concerned can enjoy the activities especially those in the learning process in the classroom.

Learning Concentration is a concentration focus of thoughts and deeds on a certain object to reduce or set aside things that are not related to the object studied. The poor quality and learning achievement of students are mostly caused by the weak ability to concentrate while studying. The common problem of the students is having a branched mind while learning. It arises without unexpectedly, such as thinking about old problems, desires, and all the lessons they receive. It is highly disturbing the process of concentration of study. Students often experience concentration difficulty during the study. It usually happens on the lessons with high difficulty level, such as the subjects related to science or social sciences. Concentration difficulties will be more severe if the students learn forcedly.

Concentration is defined as a state of thinking that can be activated by sensation inside the body. A pleasant feeling is needed to activate the sensation that can sharpen the concentration. The core of the concentration is to train students ' attention because the more often somebody pays attention to something in detail and carefully, the better their concentration is. Therefore, the basis of the concentration training is to pay attention to a certain object carefully. If the students feel very difficult to concentrate and always find the concentration broken, they are not accustomed to paying attention to something carefully and meticulously. Their mind is always fragmented and branched out with various other things. Hence, they find it hard to do during learning at school or hard to understand the explanation of the teacher. The students should develop active learning patterns and be brave to frankly tell the teachers or friends if they do not understand the lesson. Before conducting the learning activity, their mind must be completely clear and fresh. to guarantee that the learning target is optimally achieved, ice breaking is necessary to refresh the physic and mind of the students during learning. Because, a long learning requires a high concentration, and as a result the brain becomes tired to think clearly. And, ice breaking could rest the student's brain for a while. Ice breaking can effectively increase the concentration of the students' learning [10]. Therefore, this research aims to increase the concentration ability of the students in MTs Surya Buana, which is still less, through ice breaking. 


\section{METHOD}

This study employs a classroom action research to solve the concentration problems of students by using the most efficient and effective learning strategies in the common situation. Action research assumes that knowledge can grow from the experience, especially that gained through action. Under the assumption, the average ability of people can be possibly upgraded through the actions research. Researchers who conduct action research are perceived to have the expertise to change the conditions, behaviour, and the ability of students, who are the current research target.
This research consists of two variables, namely the independent variable and the dependent variable. The independent variable in this study is ice breaking. Ice breaking activities are carried out by providing motivation, yells, and videos of the ice breaking movement. While the dependent variable is the concentration of student learning. Students have difficulty concentrating while learning. Students less concentrate in learning process indicate unfocused behaviour. Students' learning concentration can be measured by indicators in Table 1 .

Table 1 The Concentration Assessment Rubric

\begin{tabular}{|l|l|}
\hline \multicolumn{1}{|c|}{ The Concentration Criteria } & \multicolumn{1}{|c|}{ Indicators } \\
\hline Not Yet Developed (BB) & $\begin{array}{l}\text { Students do not focus on the instructions given by the } \\
\text { teacher }\end{array}$ \\
\hline Start Evolving (MB) & Students focus when reminded by the teacher \\
\hline Developing According to Expectations (BSH) & $\begin{array}{l}\text { Students focus automatically following the intrusion of } \\
\text { learning }\end{array}$ \\
\hline
\end{tabular}

This study begins with preliminary observations or pre-cycle to identify the problems at school. After we are aware of the students' lack of concentration during studying, ice breaking is made to solve the problems. This research is conducted in MTs Surya Buana Malang. The research subjects are the students of class VII consisting of 3 classes, A, B and C. There are 86 students. The research subjects are all of the students of class VII because they have experienced a transition from the elementary school. They are in the process of adaptation with friends and the new school.

The action class research is designed by using the Kurt Lewin's model, which consists of input, transformation, and output. During the input, an early diagnosis early on the personal problem or groups of students. The problem identification Data are collected based on the feedback results of students' day-to-day performance evaluation. The researchers conduct a preliminary studies before setting the action research.

The research design is made by using two cycles. One cycle consists of two meetings. In case the 2meeting study has not made any improvement, the second cycle or even the third is performed until it reaches the target. Ice breaking is conducted at the beginning and middle of the learning for 5 minutes. The ice breaking in the middle of the lesson is given every 25 minutes.

The study consists of four principal components that can support the research steps: (1) planning, (2) action, (3) observation, and (4) reflection [11]. The research plan is described in figure 1.
The research instrument an observation sheet that contains students' activity. The results of the observation are analysed by using descriptive analysis method. Descriptive analysis is aimed at seeing the trend on the indicator variable through frequency distribution by using the following percentage formula [12].

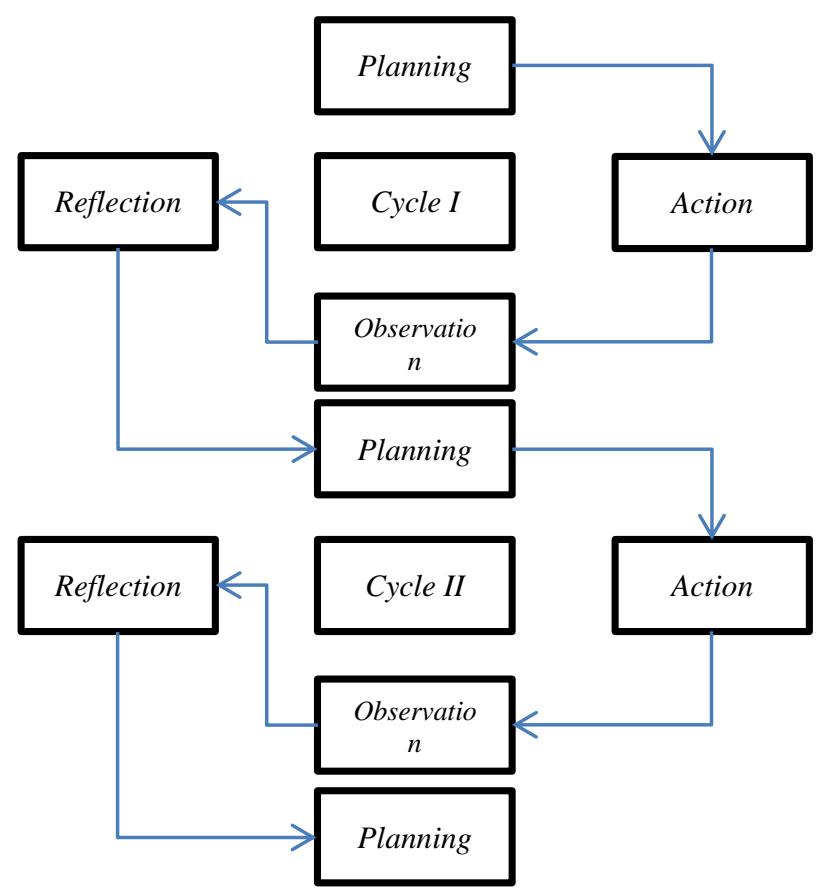

Figure 1 Research Design 
$P=(F / N) \times 100 \%$

Description

$\mathrm{P}=$ the percentage of the number of students involved

$\mathrm{F}=$ the number of students involved

$\mathrm{N}=$ The overall number of students
The success criteria are based on data interpretation in practice of ice breaking to student learning concentration. Arikunto and Safruddin are determining the criteria for measuring success activities using formulas prosentase as follow.

Table 2 Criterions for the Success of Ice Breaking Implementation on Student' Concentration

\begin{tabular}{|c|c|}
\hline Success Level & Qualification \\
\hline $85-100$ & Very good \\
\hline $70-84$ & good \\
\hline $55-69$ & Enough \\
\hline $46-54$ & Less \\
\hline $0-45$ & Very less \\
\hline
\end{tabular}

Based on Table 1 this research using the standard of success with a concentration score of achieving sufficient qualifications. Determination of sufficient qualification, because ice breaking has not been implemented at the beginning of the lesson.

\section{RESULT AND DISCUSSION}

Classroom action research is conducted in two cycles, cycle 1 and cycle 2 . The cycle one is conducted in two-meeting times. The researchers use communication tools as a medium for ice breaking in the learning process. In the first cycle, the students' learning concentration has not reached the target yet.
They are unfamiliar with the ice breaking, so they are still confused with the teacher's instructions.

The second cycle has the same objective, which is to improve the students' concentration through Ice Breaking. In the second cycle, ice breaking manages to reach the target. They are highly concentrated with great attention on the instructions given by the teachers during learning process.

The comparison of the results of the use of ice breaking in the first and the second is provided in the Table 3 .

Table 3 The students' concentration results in cycle 1 and 2 .

\begin{tabular}{|l|c|c|c|}
\multirow{2}{*}{ Number } & \multicolumn{3}{|c|}{ Average } \\
\cline { 2 - 4 } & LD & D & DE \\
\hline Cycle 1 & $17 \%$ & $33 \%$ & $50 \%$ \\
\hline Cycle 2 & $10 \%$ & $23 \%$ & $67 \%$ \\
\hline
\end{tabular}

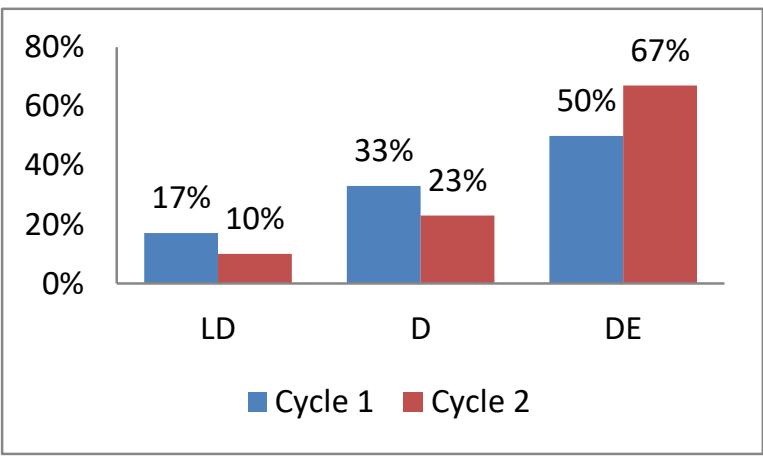

Figure 2 The students' learning concentration results

Figure 2 is the result in histogram visualization. Table 3 and Figure 2 illustrate is comparison results of cycle 1 and 2 show that the students' ability in the category of Less Developing (LD) is less than 7\%. The students with Developing (D) concentration level decreased by $10 \%$. While those who have reached the
Developed as Expected (DE) level increase by $17 \%$. The research results show that the implementation of Ice Breaking in the IPS classroom can increase the students' learning concentration level. The game eradicates the students' boredom during learning. They are highly motivated to perform the learning activities.

In the Cycle 1, there are a few notes of the observations results that need a follow up from the learning through ice breaking. The result of cycle 1 shows that learning with ice breaking cannot improve the students' concentration. Because, they are unfamiliar yet with learning process interspersed with an ice breaking game, so they become rowdy and confused with the teacher's instruction. Because the ice breaking is newly applied, so it takes the adaptation and habituation process to accustom the forms of games or the instruction must be followed by the students that they can enjoy and run the process of ice Breaking with fun. Besides, it has also become one of the special 
obstacles in the implementation of cycle 1. Besides, a less creative ice breaking may cause the students less interested in the teacher's ice breaking instruction. Therefore,

In cycle 2, the students' learning concentration has evolved according to the expectations. It increases by $17 \%$. The increase is due to the interesting design of ice breaking. The teacher uses videos that contain the current songs and followed by exiting movements, so they simply follow the movements in the video. The observation results the use of video can effectively improve the students' concentration more. The process of improving the students' concentration on social science subjects through ice breaking via interesting videos runs effectively. The students focus on following the learning instruction. Thus, it concludes that the social science students prefer to learn by audio visual because it is more interesting with pictures and sound. Students are very enthusiastic in following the ice breaking process because during the learning, they can take a break to refresh their brains with various activities, such as watching videos and playing games while learning directly. The activity can break the boredom in learning, so they are more motivated to learn in the next class.

Learning by playing, like an ice breaking, is a fun, educating, and beneficial activity to improve the ability of thinking, passion to learn, develop personality, bring the relationships between teachers and students, then channel the activities of students, and so on. Educational games also mean a form of activity performed to obtain pleasure from the way or educational tools used in the activities of playing. Educational game is an educational activity integrated with games. The results of the observations at the time of learning using the ice breaking show that the students learn with enthusiasm and fun. Therefore, ice breaking successfully increases the concentration of student in learning social science because they learn happily. Learning by ice breaking can break boredom, anxiety, and fatigue because students can take a rest for a while from the learning routine by doing motion-free and cheerful activities. Moreover, social science must have a lot of memorization and the activity is often monotonous, so the students feel bored if the teacher is not that creative in using methods and appropriate learning media.

Learning with ice breaking can help students remember the lesson of social science. A lesson which is integrated with ice breaking will be easier to deliver. The information in the lesson will be remembered longer by the students because they learn by involving the emotions. Ice breaking can serve as support to remember the lesson because students are being concentrated [13]. Ice breaking in the classroom could break un conducive condition, maintain the students' consistency in learning, and establish a good relationship between teachers and students in the class, so the students can easily remember the lesson [14]. A pleasant atmosphere between teachers and students or among the students themselves can let them enjoy the learning activities. It is also good to increase their learning concentration. The concentration will appear and happen automatically if the student can enjoy the activities. In addition, in terms of the teachers' perspective, active learning is where the teacher should strive to create a dynamic learning atmosphere with full of activity, so the students will be active to ask, to question, and deliver ideas, things that will make students more excited because the focus of learning is not only on the teacher (active teacher learning) but also student-cantered (students active learning). Thus, the students feel they have their own responsibility.

Ice breaking is an effective way used to break the less conducive atmosphere, such as tired, bored, and lazy to re-learn [15]. Ice breaking can make the students fresh, so the performance of their brain is optimized. Ice breaking which is integrated with the lesson and the students' conditions as well as the environment can increase the concentration of students' learning. It also brings their concentration back when they begin to get bored following the study [16]. It can maintain the physical and psychological condition of the students to be comfortable in absorbing the information, so they have a high absorption level. Creating a fun classroom atmosphere thorough the Ice breaking can make students relaxed and resting, so it can regulate the students' psychological conditions as well as endurance to concentrate to receive the lessons.

\section{CONCLUSION}

The research results conclude that the learning issues decrease the students' concentration because the methods used is rather monotonous. Some students are sleepy, noisy, and talking with their own friends because they feel bored with the teaching method. Therefore, the materials conveyed is less accepted by the students. The above problems can be overcome by using ice breaking in social science learning. The results of this study reveal that ice breaking can effectively increase the students' learning concentration in social science subjects. The teacher should be creative and innovative beyond the common learning rituals in conducting the learning activities in the classroom. The process of ice breaking during learning must be adapted to the conditions and needs of the students to provide stimulus and create a fun and dynamic learning atmosphere both inside and outside the classroom. Therefore, the learning process runs better and conducive. In addition, the students' brain and creativity optimization through activities beyond the lessons, such as ice breaking, needs to be implemented in the learning process. Students should also strive to pay attention to every procedure of learning delivered so that they can 
follow the learning well, stay focused, and pay attention to the teacher's instruction. It is expected that they can interpret and give response to what they have learned. Once it happens, the learning process in the classroom runs dynamically and effectively.

\section{REFERENCES}

[1] A. Fanani, "ICE Breaking dalan Proses Belajar Mengajar," vol. 6, no. 11, pp. 67-7, 2010, doi: 10.1145/3110292.3110316.

[2] W. J. S. Winkel, Psikologi Pengajaran. Jakarta: Gramedia Widiasarana Indonesia, 1996.

[3] Anang Ismail, Education Games. Yogyakarta: proU media, 2009.

[4] D. Wurjani and D. Ramadhani, "Pengaruh Teknik Pembelajaran Ice Breaking Terhadap Hasil Belajar Siswa pada Tema 6 Indahnya Persahabatan SD Negeri 1 Paya Bujok Tunong Langsa," J. Basic Educ. Stud., vol. 2, no. 1, pp. 68-78, 2019.

[5] A. F. A. Irfan, "Meningkatkan Daya Serap Siswa Pada Pembelajaran Geometri Menggunakan Ice Breaking," J. Ris. Pendidik., vol. 2, no. 1, pp. 5357, 2016.

[6] Basyarudin, "Peningkatan Efektivitas Pembelajaran Ips Melalui Penggunaan Ice Breaker Humour Di Kelas V SD Negeri 22 Bengkalis," J. Pendidik. Tambusai, vol. 3, no. 1, pp. 274-284, 2019.

[7] E. I. Febriandar, "Pengaruh Kreativitas Guru Dalam Menerapkan Ice Breaking Dan Motivasi Belajar Terhadap Hasil Belajar Siswa Sekolah Dasar," Briliant J. Ris. dan Konseptual, vol. 3, no. 4, p. 498, 2018, doi: 10.28926/briliant.v3i4.253.

[8] M. R. Setyani and Ismah, "Analisis Tingkat Konsentrasi Belajar Siswa Dalam Proses Pembelajaran Matematika Ditinjau Dari Hasil Belajar," Pendidik. Mat., vol. 01, pp. 73-84, 2018.
[9] A. Nuryana and S. Purwanto, "Efektivitas Brain Gym dalam Meningkatkan Konsentrasi Belajar Anak," J. Edukasi Mat. dan Sains, vol. 1, no. 1, pp. 88-98, 2016, doi: 10.25273/jems.v1i1.778.

[10] S. Maryani, "Efektivitas Penerapan Metode Ice Breaking Dalam Melatih Konsentrasi Siswa Terhadap Pembelajaran Fisika.” Jurusan Pendidikan Fisika FKIP Universitas Mataram.

[11] S. Arikunto, Penelitian Tindakan Kelas. Jakarta: Bumi Aksara, 2006.

[12] S. Arikunto, Dasar-dasar Evaluasi Pendidikan. Jakarta: Tarsito, 1999.

[13] Linda, "The Implementation Of Ice Breaking On Mathematics 3 Subject At Mathematics Education Study Program Of STKIP Syekh Manshur" vol. 3, pp. 110-117, 2019.

[14] M. F. Luthfi, "Pembelajaran Menggairahkan Dengan Ice Breaking," J. Stud. Islam Madinah, vol. Vol. 11, no. 1, pp. 103-107, 2014.

[15] F. Harsyad, A. Afiif, and A. I. Prasasti Abrar, "Studi Komparasi Penggunaan Ice Breaking Dan Brain Gym Terhadap Minat Belajar Matematika Siswa Kelas Vii Smp Negeri 21 Makassar," MaPan, vol. 4, no. 2, pp. 185-199, 2016, doi: 10.24252/mapan.2016v4n2a3.

[16] A. Mulyana, "Restorasi Fokus Belajar Siswa melalui Ice-Breaking," Educivilia: Jurnal Pengabdian pada Masyarakat, vol. 1, no. 1. p. 1, 2020, doi: 10.30997/ejpm.v1i1.2593.

[17] M. E. Nasrullah, "Permainan Ice Break Sebagai Motivasi Dalam Pembelajaran Yang Humanis," VICRATINA J. Pendidik. Islam, vol. 3, no. 2, pp. 105-121, 2018. 